\title{
Research on the Vocational English PBL Teaching Model Based on Autonomous Learning
}

\author{
Weijuan Zhang ${ }^{1, \text { a }}$ \\ ${ }^{1}$ Chongqing Vocational College of Public Transportation, Chongqing, China, 402247 \\ ${ }^{a}$ email,
}

Keywords: Autonomous Learning, PBL, Teaching Model

\begin{abstract}
In recent years, with the advancement of higher vocational college English teaching reform, exploring new teaching mode, optimizing the teaching process and training the students' ability of autonomous learning in higher vocational colleges has become an important direction of higher vocational English teaching reform. In this paper, the author's tentative explorations of the application of PBL teaching mode in classroom teaching to improve students' autonomous learning ability has achieved good effect, making "teaching" and "learning" complements each other.
\end{abstract}

\section{Introduction}

Currently, the college English teaching is in a transition period, the boundaries between university English and high school English gradually blurred and with the gradual improvement of multimedia, as well as the growing popularity of the network and English learning environment, college English teaching has become an unnecessary duplication of high school English teaching. This will inevitably result in the examination-oriented education on teaching, inefficient and time-consuming and generally slack on the effectiveness of learning. ${ }^{1}$ Ministry of Education promulgated the "College English Curriculum Requirements (for Trial Implementation)" that "teaching objective of College English is to improve the ability of independent learning", "training students' English proficiency." ${ }^{2}$ That is, the learning ability of students' development and the formation of their personalized learning approach is a measure of an important indicator of college English reform in the new era success.

\section{Review on Current Several Major Teaching Modes}

The scholars have different views of definition of "teaching mode" at this stage. According to Longman Dictionary interpreted as linguistics, (1)the representation of a theory (representatives of theory); (2)something or someone used as a standard or a goal for learners define the Modern Chinese Dictionary as "a certain standard form of things or people can shine. I believe that the teaching mode is understood under the guidance of teaching philosophy, teaching and learning in some of the elements formed in the teaching and learning environment combine to form organic relationships in the teaching process to be verified template pattern.

The Traditional Grammar Translation Teaching Mode. The process of teaching teachers play a leading role in the authority, the curriculum generally weekly reading and writing section 3, section 1 Listening and Speaking. It relies mainly on students' language acquisition and teachers teach teachers to complete the tasks assigned to get. Evaluation method is 3:7, which usually results $30 \%$ of the final grade, $70 \%$ of the final grade. This mode is the most common teaching methods used in vocational colleges. This mode of teaching so that students learn in a passive state,

English Classroom Teaching Model with Multi-media Assist. The teaching place is in a large modern multi-media classroom, teachers have large classes through the network platform and by means of multimedia, explain the important and difficult knowledge in a targeted manner, combine multi-dimensional input language with literacy and heard, thereby trying hard to enhance students' language proficiency. This model and the traditional grammar-translation method, exactly the same, is still a "primary teacher" form, exposed many problems to be resolved to seek a better way of 
teaching.

English Teaching Model Based on Different Levels. The teaching model based primarily on the United States applied linguists Kranshen in Second Language Acquisition Language Input Hypothesis theory proposed. ${ }^{4}$ The background of implementation of the teaching mode is that students' English ability and accept ability varies after increasing enrollment which brings a greater challenge to English teaching. "Stratification Teaching" also known as group teaching, is intended to provide maximum learning conditions for students at different levels. Compared with the traditional teaching mode, teaching grade teaching objectives clearer, help teachers to find more suitable for the characteristics of students teaching methods for teaching, but there are many inadequate. The most obvious flaw is a hierarchical manner is based on student achievement, such a test moves of way does not fully reflect the true students' language proficiency; teaching methods after classification, will be difficult to avoid the continuation of traditional teaching methods, namely, teacher "talk" student "listen," the main form of teaching seems single rigid.

Several current major mode of teaching is difficult to adapt to the new era of college English teaching; the author tries to use PBL model in classroom teaching.

\section{The Description of PBL Model}

PBL (problem-based learning) is problem-based teaching and the theory is from the mid-fifties of the twentieth century American medical education, emphasizing student self-exploration-based learning. Students subject to the guidance of teachers and take the initiative to collect, analyze information in a way the study; to acquire and apply knowledge, problem-solving learning activities. Thus, significant differences with traditional teaching theory is that, in the PBL model framework, not only is to train students to understand, to recite, like repeat of knowledge, more important is the need for students to learn how to use various sources of information to find their own required materials, and processes the information, organize, summarize, refine ideas or information required from the student. PBL, as a self-learning model, designed to fully mobilize and play the initiative of students, shaping the independence of the learner, and under the guidance of teachers, closed out textbooks, mutual cooperation, to open research resources. This will enable learners to gradually have the ability in the future life and career to continue learning, to pave the way to achieve lifelong learning. PBL basic process parameters as follows:

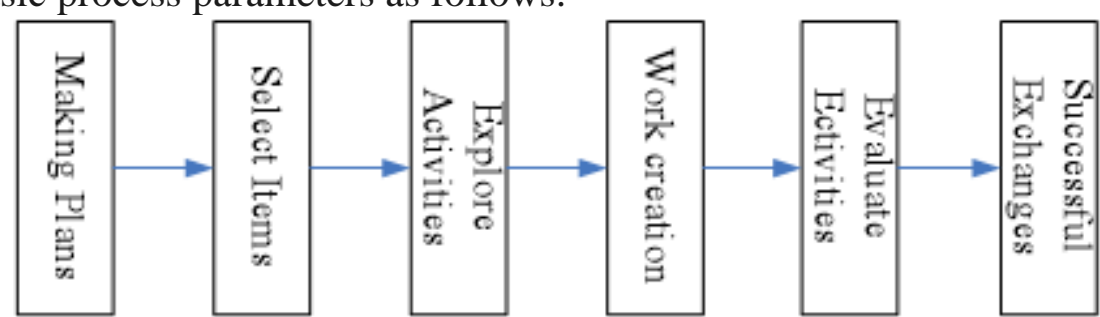

PBL has a strong theoretical foundation, constructivism is an important support. Specific points can be interpreted as follows: the "student-centered" focus on capacity and quality, the emotional focus on learners, learners are encouraged to take their own interests, individual needs to experiential learning, active exploration, in order to adapt to different cultural communication and the social environment, and strengthening address the challenges of energy.

\section{The Application of PBL Mode in Classroom Teaching}

The PBL-Based Classroom Reports. PBL model emphasizes "teaching" and "learning" unified in two ways. Common activities of students and teachers compose the teaching process. PBL model create a natural, a real context for student exchanges to build a good platform. Teachers teaching according to the theme and objectives of the course content and set the different units, and strive to create real-life scenarios linked themes, and set the problems caused by students' curiosity, to mobilize students to reserve existing knowledge in the brain, and stimulate the learner actively searching thirst for knowledge related to the problem of information. PBL mode basic flow diagram 
shown in the following table, according to the project time progress can be divided into front, middle (implementation), a later stage.

\begin{tabular}{|c|c|}
\hline \multirow{2}{*}{ Pre-stage of the Project } & Teachers Introduce Project Status \\
\cline { 2 - 2 } & The Plan of Students' Projects \\
\cline { 2 - 2 } & Teachers Review Students' Plan \\
\cline { 2 - 2 } Project Implementation Phase & Students Revise and Improve The Plan \\
\cline { 2 - 2 } & Student Research Project \\
\hline \multirow{2}{*}{ After the Project } & $\begin{array}{c}\text { Students Show Project Outcomes With } \\
\text { Report Form }\end{array}$ \\
\cline { 2 - 2 } & $\begin{array}{c}\text { The Project Team Answers Questions } \\
\text { from Teachers and Students }\end{array}$ \\
\cline { 2 - 2 } & \begin{tabular}{c} 
Teacher and Student Senate the Project \\
\hline
\end{tabular} \\
\hline
\end{tabular}

Then take a look PBL Mode in Higher Vocational English Class.

The author's school is used by the Chongqing University Vocational planning materials published "Growing English." Before implementation of the project, the teachers firstly give a detailed exposition to student on the characteristics and evaluation criteria PBL learning. Depending on the theme of each unit, the student groups themselves, different groups of the same unit responsible for the different sub-units. Teachers and students can jointly proposed project. The theme of the unit is about the college students work part-time (part-time jobs of college students). The unit can be divided into four groups carried out by prep classes, and other ways to search for information on the network, each submitted sub-topics of each group, and by teachers after the modification, the final topics discussed were:

(1) part-time job: new experience for college students

(2) Is part -time job all helpful?

(3) What kind of part-time job do college students take?

(4) Study or part-time job, which comes first?

Thesis, once established, each group division of labor, the project research. For example, some students responsible for the network to find information; some students responsible for writing the document; some people responsible for making PPT. Requirements PPT presentation of the report is mainly used simple English and pictures, additional Chinese statements when necessary. Problems encountered in the project plan, before coaching teachers, students and then to solve it yourself.

At the end of the unit, students involved in the project, group action, on topics established in the form of PPT turn the podium to elaborate. After the report is complete, the Panel accepted questions from the audience of teachers and other group members, and to answer in plain English. Scoring evaluation report done by all three parties. First party, that party self-assessment of the performance of the situation and prepare the stage forth to do self-assessment scores accounted for $5 \%$ of the overall assessment report; the second party: peer review, ie evaluation team from the audience, the audience student audience will show the PPT, language fluency and satisfaction to answer questions of the major aspects of this score, $15 \%$ of the total assessment score; there are $80 \%$ of the heavyweight score is derived from the outset to participate in the project which teachers given, according to the scores given by each group is mainly comprehensive student performance and adaptability.

PBL teaching mode can mobilize more students to participate in class discussions as far as possible to, greatly improve the students' participation. Teachers put into learning tasks meaningful to-life scenarios, so that students in small groups collaborate to complete tasks, or indirect learning 
cultural knowledge behind the problem. Students in the part-time units, for example, set forth in order to complete sub, the students hands-on to find and cite a wealth of information, such as foreign college students work part-time situation, and the contrast with the domestic situation, a series of comparative draw relevant conclusions. Students can make full use of these conclusions and opinions in small papers reporting the end of the semester.

Change the Assessment Methods and Introduce the PBL Term Paper. Adjust the conventional assessment methods. Assessment methods most Higher Colleges English courses still follow a more traditional model, namely Overall score $=$ normal results $(60 \%)+$ final grade $(40 \%)$. This evaluation approach is more rigid; it cannot fully reflect the true students of language proficiency. The author taught students in the class, changing the previous assessment methods. Overall score consists of the following elements: 1) classroom report (25\%) 2) term paper (25\%) 3) final grade (40\%) 4) extra points (10\%). Specifically description is as follows: class presentations and term papers are PBL model expansion; fourth feature extra points, mainly for students who usually was particularly prominent, and then encouraged some extra points, but also to achieve the gap of scoring, and opened the learning level gap logo.

The basic procedure is shown below:

\begin{tabular}{|c|l|}
\hline \multirow{5}{*}{ Pre-stage of the Project } & $\begin{array}{l}\text { Teacher presents the relevant } \\
\text { requirements and evaluation criteria } \\
\text { of term papers }\end{array}$ \\
\cline { 2 - 2 } & $\begin{array}{l}\text { Students determine the initial thesis } \\
\text { topic and outline drawn }\end{array}$ \\
\cline { 2 - 2 } & $\begin{array}{l}\text { Teachers advise students on topics } \\
\text { and outline }\end{array}$ \\
\cline { 2 - 2 } Project Implementation Phase & $\begin{array}{l}\text { Students makes the targeted } \\
\text { modification }\end{array}$ \\
\hline & $\begin{array}{l}\text { Teachers review the first draft of the } \\
\text { students and proposed changes }\end{array}$ \\
\cline { 2 - 2 } & Students revise the first draft \\
\hline \multirow{5}{*}{ After the Project } & Students submit papers \\
\hline & $\begin{array}{l}\text { Student briefly discusses the paper } \\
\text { key points and answer questions }\end{array}$ \\
\cline { 2 - 2 } & Teachers reviews the students' reply \\
\hline
\end{tabular}

After students become familiar with PBL teaching mode, teachers can introduce PBL semester paper in the period. And brief writing requirements and assessment criteria, such as the selection of the topic, data collection, language reference and applications. In this period, the students have learned in the unit range, determined topics according to their interests, and the use of spare time to complete the first draft. Writing requires flexible, minimum standards and achieves the highest standard binding. Minimum standards applicable to language students weak foundation, neat writing requirement, the basic point of view is correct, the word count is about 100 words. The highest standards are applicable to language proficiency of students is relatively good, basic requirements for accurate expression, word count 300 words. First draft completed, reviewed by the teacher, propose amendments.

End of the semester, students submit papers revised and prepare for the defense. Reply link is 5\%. The main aspects of defense have two parts: 1) self-presentation (1-2mins) 2) Q \& A session 
(2-3mins), which is also a good way to exercise students' verbal ability. Finally, teachers review final draft for thesis. (The final draft is of $15 \%$ of the paper).

After a semester of PBL teaching, the author investigates 119 students from Chongqing Vocational College of Public Transportation in the form of a questionnaire. We have 119 actual recoveries and the recovery rate is $100 \% .43 \%$ of the students said after PBL teaching, self-learning ability has been greatly improved. Most students think PBL teaching mode has improved their ability to make PPT and present the classroom report; ability to search and process literature and capacity to communicate and assist peer. It is visible that the vast majority of PBL students are satisfied and basic satisfied.

\begin{tabular}{|c|c|c|c|}
\hline $\begin{array}{c}\text { Capacity Development } \\
\text { Improvement Degree }\end{array}$ & $\begin{array}{c}\text { Improved } \\
\text { Greatly }\end{array}$ & $\begin{array}{c}\text { Improved A } \\
\text { Little }\end{array}$ & No Improvement \\
\hline Make Class Presentations & $38 \%$ & $42 \%$ & $20 \%$ \\
\hline PPT Production & $34 \%$ & $39 \%$ & $27 \%$ \\
\hline Literature Search & $36 \%$ & $38 \%$ & $26 \%$ \\
\hline $\begin{array}{c}\text { Sorting, Processing, Handling, } \\
\text { Exchange Information }\end{array}$ & $39 \%$ & $40 \%$ & $21 \%$ \\
\hline Analysis, Cope, Solve Problem & $32 \%$ & $38 \%$ & $30 \%$ \\
\hline Self-Learning & $43 \%$ & $40 \%$ & $17 \%$ \\
\hline $\begin{array}{c}\text { Cooperation and Communication } \\
\text { among Peers }\end{array}$ & $30 \%$ & $45 \%$ & $25 \%$ \\
\hline Reply Thinking & $20 \%$ & $31 \%$ & $49 \%$ \\
\hline
\end{tabular}

Advantage 1: PBL teaching mode helps enhance students' creative thinking ability. Dennis pointed out and PBL is an excellent container promotes thinking. Students promote development and enhance self-learning ability by gathering information, analyzing data, and other ways to create a hypothesis. In response to the various problems of the scene, they develop their creative thinking.

Advantage 2: PBL teaching mode helps to foster students' ability to learn. In the teaching process, teachers shift from facilitator disseminators of knowledge, guide and manager. And to grant greater autonomy to the students and let students decide what needs to learn and how to learn. In order to successfully complete the task, students need a custom study plan, self-motivated, independent study, self-directed learning; knowledge application to build a new settlement complex practical problems. It may also exercise the ability of students in many aspects, such as inductive deductive ability, verbal ability and the ability of lifelong learning. These will pave a good foundation for the future to continue to study or work.

Advantage 3: PBL help teachers grasp the teaching effect.

The best feedback of teaching effectiveness is whether the issue is resolved. The feedback information received from putting forward questions to solve problems allowing teachers to understand students' understanding of what they learn to grasp the situation, in order to adjust teaching schedule, change teaching strategies to enable students to more actively and boldly participate in classroom activities.

\section{Reflection}

PBL has changed the way students learn, changing the traditional role of classroom teachers and students, but with the deepening of course, it has also found some problems.

Problem 1: differences between students English level directly affects the PBL effect. Effective implementation of PBL requires students to appropriate knowledge and ability to protect basis for poor students cope with simple book knowledge is bloated and cannot be separated more time and energy to carry out research projects and expand extracurricular knowledge. PBL can improve students 'motivation to become the premise that a given task is within the range of students' abilities, and through our efforts, by means of certain external conditions, can be successfully completed, and from which to obtain problem-solving sense of joy and accomplishment. 
Problem 2: unsuccessful cooperation. When assigned the task group, some students habitually love evades responsibility, unwilling to assume the role, which led to the uneven distribution of tasks, the distribution ratio imbalance. To avoid these phenomena, teachers should be given a lot of positive, effective guidance and encouragement in the task allocation and implementation process, the full implementation of good supervision, reminders and encouragement duties.

Problem 3: Some teachers are not enough to grasp the essence of PBL. Some teachers blindly pursue classrooms lively scene, in the arrangement of tasks, in order to seek more interested in the topic of the student, there is a tendency from the teaching materials, teaching content design deviates from the objectives of the teaching unit, the arrangement of the task only stay on the surface form, just to complete the task done, the result will be "relaxed but over."

\section{Conclusion}

PBL teaching mode is consistent with the language learning cognitive law and can meet the basic conditions required for language development. The teaching model is designed to train high quality vocational English talents. Current, PBL has made some achievements, but there are many variations. This requires teachers flexibility combine with other teaching methods and means, continue to reflect and summarize in the actual teaching process to make it truly suitable for students of different age groups, different levels and different abilities to improve the students' English proficiency services.

\section{Acknowledgements}

Fund Project: Chongqing 2015 Higher Education Teaching Reform Project (153349)

\section{References}

[1] Zhang Lan. Ningxia University, Vol. 4 (2009) No 53, p.25-26

[2] College English Curriculum Requirements. Shanghai Foreign Language Education Press, 2014. p. $10-13$

[3] Lai Jigang. Foreign Language Teaching and Research, Vol. 4 (2010) No 19, p.306

[4] Little, D. Learning Autonomy: Definitions, Issues and Problems. Dublin: Authentik, 1991. p.28

[5] Liu Hai. China Adult Education, Vol. 1 (2006) No 27, p.57-60

[6] Luo Yonghe. Northwest Medical Education, Vol. 2 (2007) No 27, p. 28-35

[7] Ding Houyin. Foreign Language Teaching, Vol. 3 (2009) No 27, p. 40-41

\section{重庆市江津区长城路环卫所综合楼 邮编 402260 电话 15310296590 张维娟}

